Citation: C. Carreras i Verdaguer, L. Frago Clols, E. Montesinos Ciuró (2020). Rescaling Retail and Consumption in the Contemporary Barcelona Area. Bollettino della Società Geografica Italiana serie 14, 3 Special Issue: 37-49. doi: $10.36253 /$ bsgi-994

Copyright: (c) 2020 C. Carreras i Verdaguer, L. Frago Clols, E. Montesinos Ciuró. This is an open access, peerreviewed article published by Firenze University Press (http://www.fupress. com/bsgi) and distributed under the terms of the Creative Commons Attribution License, which permits unrestricted use, distribution, and reproduction in any medium, provided the original author and source are credited.

Data Availability Statement: All relevant data are within the paper and its Supporting Information files.

Competing Interests: The Author(s) declare(s) no conflict of interest.

For Italian evaluation purposes: In spite that the three authors are responsible for the whole article, Carles Carreras especially worked on the first, fourth and fifth sections, Lluis Frago on the third and Eduard Montesinos on the second one.

\section{Rescaling Retail and Consumption in the Contemporary Barcelona Area}

\section{Il rescaling del commercio e del consumo nell'area della Barcellona contemporanea}

\author{
Carles Carreras i Verdaguer, lluís Frago Clols, Eduard Montesinos \\ CiURó \\ Geography Department, Universitat de Barcelona \\ E-mail: ccarreras@ub.edu; llfrago@ub.edu; edmontesinos1@gmail.com
}

\begin{abstract}
Consumption is one of the less know variable in urban studies. The article presents a general overview of Catalan and Barcelona study case, summarizing almost thirty years of research, with the goal to isolate the main contemporary trends of retail and consumption in the area. The recent economic processes in the Catalan context are analyzed in the first place. At the same scale, the level of analysis is again recentered on the changes into the metropolitan and regional Barcelona, focussing in the perspective of the old slogan of Catalonia-city. The necessity of the restructuration of the scale of the analysis is proposed. After, the lens is adjusted to the city of Barcelona case, focussing on the relevant change in his traditional centrality. Finally some future trends are advanced.
\end{abstract}

Keywords: Barcelona, Catalonia, centre, Metropolitan region, periphery, scale.

Riassunto. Il consumo è una delle variabili meno conosciute negli studi urbani. Larticolo presenta una panoramica generale sul caso di studio catalano e di Barcellona, sintetizzando quasi trent'anni di ricerca, al fine di individuare le principali tendenze contemporanee del commercio e del consumo nell'area. In primo luogo vengono analizzati i recenti processi economici nel contesto catalano. Alla stessa scala, il livello di analisi viene nuovamente centrato sui cambiamenti nella Barcellona metropolitana e regionale, concentrandosi sulla prospettiva del vecchio slogan della Catalogna-città. Si propone la necessità di ristrutturare la scala di analisi. Successivamente, lobiettivo viene spostato sul caso della città di Barcellona, focalizzando l'attenzione sul rilevante cambiamento nella sua tradizionale centralità. Infine sono prospettate alcune tendenze future.

Parole chiave: Barcellona, Catalogna, Regione Metropolitana, periferia, scala.

\section{Introduction}

As members of a long tradition team on retail studies (Carreras 1989), the authors of this paper have set up their research focussing both in the city of Barcelona (Carreras et al. 1990; Carreras 2003a) and the region of Cata- 
lonia (Frago 2011; Carreras, D’Alessandro 2017, 36-38 and 68-70), and their relations. These researches have encountered some difficulties, mainly related with the fact that since the last decades of the XX Century the increasing number of all kind of shops, stores and retail formats has been inversely proportional to the availability of their information sources. This fact has forced researchers to deal with methodological issues, as the use of indirect sources, especially some fiscal taxes until their total extinction in 2004, and the use of different qualitative techniques of research, as questionnaires and direct fieldwork. Due to this reason, studies absorbed large amounts of economic resources, needed wide teams of personnel, took long periods of elaboration, and were local scale focussed.

The development of the scientific research on retail studies under those difficult conditions contrast with the most common work of private consulting companies. They produced easily a huge number of reports oriented towards decision-making, both in public administration and in private companies. Those reports are based on distant observation, mainly with web mapping services. The results used to be referred to larger scales and although they were often achieved much faster, they were relatively simple and superficial.

It is in that frame that the main goal of this paper is to present a sort of a general overview summarizing almost thirty years of research on the Catalan study case, trying to isolate the main contemporary trends of retail and consumption and its territorial structure. A multi-scalar approach is used in order to achieve the goal, as well as in each scale a sort of state of the art is proposed. First, a brief analysis of the recent economic processes in the Catalan context is presented. Second, the level of analysis is recentered on the changes into the metropolitan and regional Barcelona, paying attention to the perspective of the old slogan of Catalonia-city. And third, the lens is adjusted to the Barcelona case, focussing on the relevant change in its traditional centrality. Finally, as research conclusions, some future trends are advanced.

\section{The Catalan context}

The nowadays retail structure and consumption spaces in Catalonia can be only understood in the frame of its history, in a sort of path dependency or historical process. Thus, the roots can be found in the strong commercial tradition at an international scale, mainly throughout the Mediterranean, that facilitated an earlier industrialization process in the XVIII and XIX Cen- turies (Vilar 1962), when Catalonia developed a dense retail structure. Similar to the industrial pattern, the retail structure was based on small and familiar firms, on the long Mediterranean tradition. A very regular network of market centres with Barcelona on the top, and some forty secondary cities over a myriad of local places, in a sort of Walter Christaller's distribution, that allowed a later complete political and administrative organization designed in the 1930's but not applied until the end of the 1980's (Vila 1937; Lluch, Nel.lo 1983, 1984).

During this long period of fifty years, everything changed; politically, from civil war (1936-39) to a late democracy through a long dictatorship (1939-1978); economically, with the increasing population mobility and the progressive social and economic process of modernization. The end of the dictatorship coincides in time with the beginning of the capitalist restructuration in the middle of 1970 's. The changes brought about by this new stage have already been analysed ${ }^{1}$.

Since then, there has been a double process of economic and territorial concentration. On the one hand, accumulation of capital has benefited the biggest firms, especially some international, mainly French distribution companies ${ }^{2}$ (Arribas 2002). This fact, together with the proliferation of branches and franchises has weakened the traditional small and familiar businesses. On the other hand, Barcelona has concentrated the main part of population and activities, starting a strong and diffuse process of metropolitanization. Traditional commercial hierarchies have been altered (Beavon 1977) with the introduction of new retail forms, especially the modern shopping centres. ${ }^{3}$

These new retail forms have been encouraged by the social and cultural changes of the contemporary consumption habits that accompanied the progressive increasing of population's income. For instance, expenses per capita in the city of Barcelona doubled between 1991 and 2007; slowed by the consequences of the global financial crisis, and then recovered and increased only a $13 \%$ in 2018. Per capita expenses were always bigger in Barcelona than the average of Catalonia and even more than in the whole Spain ${ }^{4}$. This increasing consumption was constantly strengthening by international tourism. Numbers of foreign tourists in Catalonia were 15.2

\footnotetext{
${ }^{1}$ The reference is to the article by Carreras, Martínez-Rigol and Morcuende in this special issue.

2 The internationalization of the Catalan economy was clearly reinforced after the integration of Spain into the European Union in 1986.

${ }^{3}$ The first real shopping Centre in Barcelona was inaugurated very late, in December 1993, long after de positive impact of the summer Olympics.

${ }_{4}^{4}$ Information from the series of the Statistical Yearbook of Barcelona.
} 
million in 2007, and 27.7 in 2019, the majority of them (47.3\%) visiting Barcelona ${ }^{5}$. In 2018, in a single city of 1,6 million inhabitants, 4.6 million people visited the temple of Sagrada Familia, for instance. Together with the massive incoming tourism, even a relevant outgoing tourism was changing the consumption patterns ${ }^{6}$.

In front of all these changes, the autonomous government of Catalonia has been aground in a long and unsuccessful legal fight against the economic liberalization both at the level of Spanish and European rules. Instead, the Catalan policy has been the protection of local, familiar and urban ${ }^{7}$ retail. The deep changes that began in the 1970's, brought about the debate -with both theoretical and applied dimensions- of the substitution of the economic base of the city.

In the Western context, it was conceptualized that these changes implied a transformation from an old industrial economy to a knowledge economy (Florida 2002; Scott 2008). The key element to understand this process is the substitution of the mass production by the flexible: for the first time it was possible to solve the problem of overproduction, adapting the supply to the potential demand. The innovations in the means of communication and transport allowed the immediate global interconnection required to maintain such a system.

Regarding the case of Barcelona and Catalonia, some different aspects of this process deserve attention. From a merely economic point of view, there have been some attempts to measure the magnitude of the loss of industry because of the adoption of the flexible production. No robust conclusions were possible to extract from this analysis, since the comparison between two different types of organization is difficult. Traditionally, the industrial companies contracted all their employees regardless of the kind of job they had. The trend for big companies since the 1970's has been to outsource, that is, to transfer certain tasks needed to complete the productive process to external companies, specialized in the provision of goods and services. Therefore, having less industrial jobs in the present than in the past does not imply that the level of the industrial production of the country is lower now than fifty years ago.

Nevertheless, when we put the focus on the new economy that substituted the traditional industrial sectors, some experts of this issue have arrived to a con-

\footnotetext{
${ }^{5}$ Information from the series of the Statistical Yearbook of Catalonia, published by IDESCAT.

${ }_{6}$ The Barcelona Tourism Board calculated 10 million annual international travels in 2019, approximately the half of all the Spanish travels to the exterior.

${ }^{7}$ Urban in the sense of centrally located shops, against the peripheral big commercial areas.
}

sensual diagnosis. For example, the regional economists headed by Joan Trullén, have emphasized the idea that what characterizes the economy of Barcelona since the first efforts to introduce the knowledge economy were the medium-low technology services in the central city and the low knowledge intensity industry in the periphery (Boix, Galletto, Trullén 2011). Other authors have conceded that in the past decades Barcelona configured more like an entertainment city that like an innovation region, where the creative workers are attracted by the quality of life of the city but struggle to find world-class job opportunities (Pareja-Eastaway et al. 2008).

This topic connects with the hegemonic discourses about the city. In the 1980's, when the strategic economic sectors were concentrating in the suburban areas (in the Mediterranean, but especially in North America) and it seemed that the cybernetic revolution would devastate all the traditional activities, the anti-urban discourses dominated (Hutton 2010). Since the 1990's, coinciding with the cultural turn in urban policies and the return of strategic economic activities to city centres (Harvey 1989), pro-urban discourses became dominant. In that context appeared the idea of the creative city. In Barcelona, the architect Oriol Bohigas, who had responsibilities in the urban planning area of the city council, fixed the official discourse. With that spirit, he wrote that the city itself was a cultural event (Bohigas 1986).

From a spatial point of view, the result of the substitution of the economic base of the city was clear. Factories almost completely disappeared in the central municipality; some industrial companies ceased to exist, while some others relocated their productive units to the industrial parks that were located in the periphery of the metropolitan area at the same time. Others transferred to other Spanish cities or elsewhere in the world (especially Eastern Europe and Asia). In the context of the resurgence of the city centres, already analysed, it is relevant to know what activities reused the most important factories that characterized the landscape of the city for most of the $20^{\text {th }}$ century. In order to know whether the knowledge economy was the main driver of the process and if Barcelona became a creative city (Fig. 1).

This analysis has shown several on-topic facts (Montesinos 2019). In the central districts of the municipality, the prevailing uses in the former industrial plots are hotels, restaurants, housing, offices, and parking. All these projects have in common the private nature of their emergence, ruled by the real estate development of the past few decades. By contrast, in those neighbourhoods that were less pressured by the real estate market and had a stronger social organization (north and southwest of the city, notably), a different sort of uses stand 


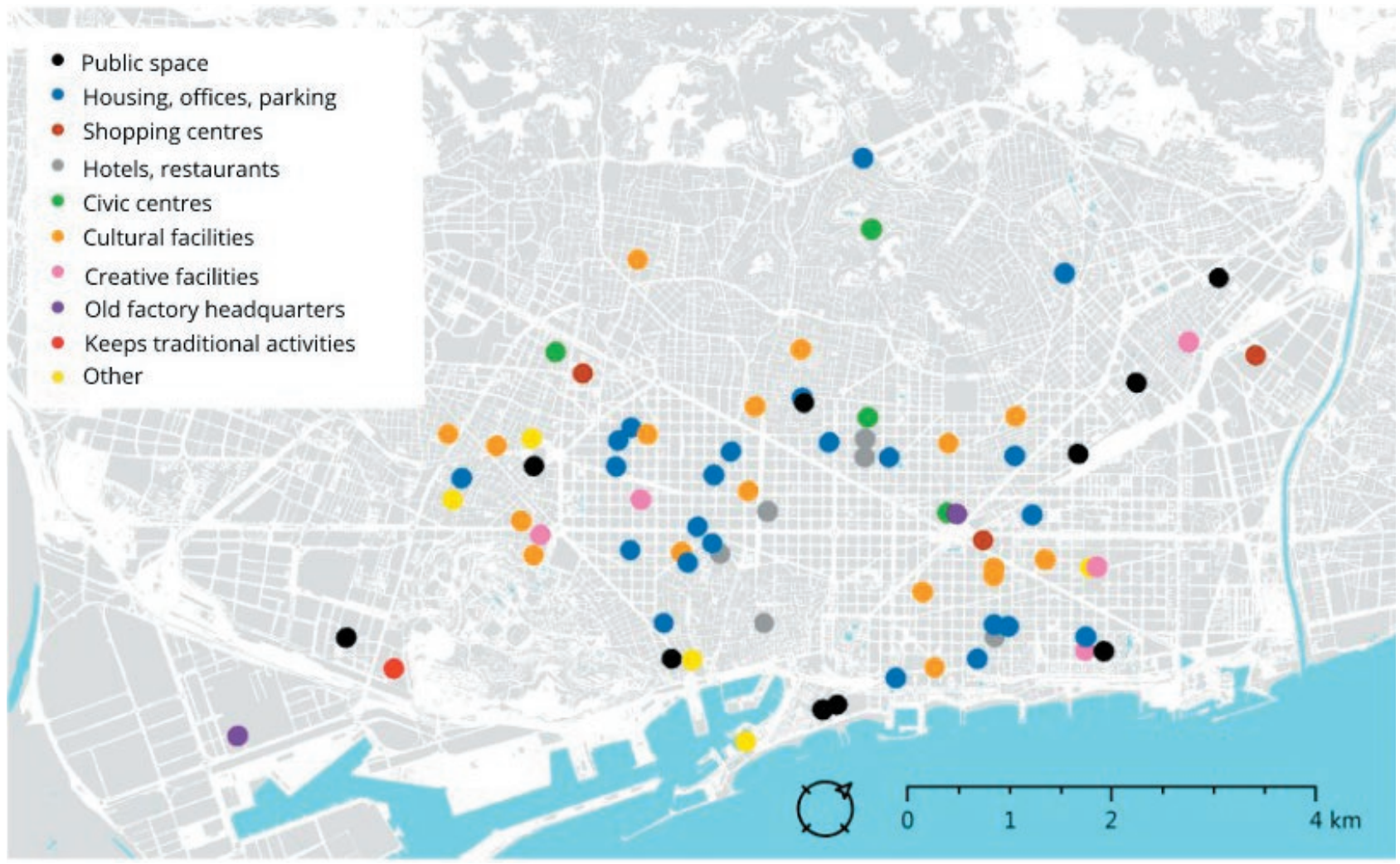

Figure 1. The new uses of former industrial factories in Barcelona. Source: Carreras et al. 2019, 128.

out, namely cultural facilities like schools and libraries and public spaces. There are cultural facilities in the central districts of the city too, but they are usually of a different kind; not of everyday utilization but of national or international reference, related to the tourism and leisure industry: museums, creative factories or cultural centres like La Bohemia factory. This last case is very illustrative because the former industrial company, a brewery, keeps its property in the city centre and contract creative workers to organize there cultural events on a regular basis (Carreras et al. 2019).

Thus, there exists a cultural sector with the strategic function in the urban economy of Barcelona to provide the values shared by the majority of consumers in the neoliberal era, epitomized by the young, cosmopolitan and well-educated creative workers. In this era, consumption has become a political action (GarcíaCanclini 1995), and so the economic powers have had to construct a hegemonic way of consuming, functional to their interests. Notwithstanding the crucial importance of these symbolic aspects of the issue, from a materialist perspective these activities have not become an economic base for the city. Land rents and real estate specu- lation are the real drivers of the economy of Barcelona since the global restructuring of the 1970's and nowadays tourism is the fuel that keeps the flame alive.

\section{Catalonia-city, a periphery without center?}

From the Catalan context, a more focused analysis on the Regional Barcelona is required, in order to understand the spatial structure of retail and consumption, which includes the relation of the city of Barcelona with the rest of the Catalan territory, that is the so called Catalonia-city. This analysis will reinforce three main axes of spatial restructuring: first, the loss of relevance of the local commercial system, mainly the county capitals; second, the integration of inner territories to new economic functions, related with the new corridors configuration, especially with logistics and tourism, which impacts on the retail and consumption spaces; third, the extension of the metropolitan area.

In this sense, the scalar restructuring of Barcelona in the context of the neoliberal economy has played a fundamental role in the articulation of urban consump- 
tion spaces. Especially since the mid-1990, when Spain's integration in the EU was consolidated as well as the associated processes of neoliberalization of the economy. The new patterns of urban and regional development, variegated and contradictory, should be analyzed through the scalar changes.

These processes of scalar restructuring overlapped previous socio-spatial structures of consumption that dialectically give rise to new urban relations. Despite the speed and intensity of changes, this restructuring have metamorphosed at a local scale previous structures as a reaction to the new totality. The territorial rescaling, selective and fragmentary, started in the 1990's, and coexists with a diversity of urban realities at a local scale. These realities are product of slow times and have had relatively few changes during the 20th century. Because of this coexistence, multiple paths of modernization have been derived (Santos 1996) producing antagonistic situations between nearby territories as a product of the different dynamics of differentiation and equalization, and different resistances to creative destruction (Brenner 2014; Smith 1984) ${ }^{8}$.

\subsection{Fragility of the local commercial system}

The traditional analysis of consumption spaces in Catalonia is rooted in a contrast between Barcelona and the rest of the territory, articulated mainly by the unequal processes of capital centralization during the industrial period. Barcelona and its area were organized by a strong industrial economy, while the rest of the territory had an agricultural base. The industrial development that arose from the reinvestment of wine growers was restricted to the most fluid areas of the metropolis (Vilar 1962). The construction of Catalan nationalism in the late 19th century deepened this contrast, as it placed the cradle of Catalonia beyond the city of Barcelona (Nogué 1991; Vives 1962).

During the industrial period, this territorial contrast was based on two processes with different temporal and spatial scales logics. On the one hand, at a local scale, a system of pre-industrial city-markets; on the other hand, at a regional scale, the production of consumption spaces based on a Barcelona logic, that was materialized by the proliferation of secondary homes ${ }^{9}$. Those spaces

\footnotetext{
${ }^{8}$ By dynamics of equalization and differentiation we refer to what Neil Smith theorizes when treating unequal development (Smith 1984), and by creative destruction to the intrinsic dynamic of implosions-explosions theorized by Lefebvre (1970), later developed by Neil Brenner (2014) for dealing with planetary urbanization.

9 There are several artists who record this type of use of the territory, including Josep Maria de Segarra and Josep Pla (Carreras 2003b).
}

emerged as an outcome of the construction of a steampowered railway infrastructure, which improved people's mobility in summers and weekends.

Moreover, the State played a key role in articulating the spaces of consumption on a regional scale, especially through the impetus given by the government to the four provincial capitals. These cities and their associated regions were the units with which the Spanish State organized its political power, until today. Those four cities were established as provincial capitals in 1833, and their function of capitals produced the demographic dominance of the city over its provincial territory that still occurs today: Barcelona concentrates $30 \%$ of the provincial population; Girona the $13 \%$; Lleida the $32 \%$; and Tarragona the $16 \%^{10}$. Despite the homogenizing role promoted by the State, the demographic dominance of Barcelona, and especially of its metropolitan area, as a result of the processes of capital centralization, enables to speak of relevant regional inequalities.

On the other hand, the thirty-eight pre-industrial market cities distributed between twenty or forty kilometers of distance have been the basis of the territorial organization in counties ${ }^{11}$ (Vila 1937). Thus, with the territorial integration promoted by capitalism, those cities became the functional trunk of the urban system of Catalonia and at the same time had the possibility to correct the macrocephaly of Barcelona ${ }^{12}$.

Since the 1970's, there have been different processes of economic and urban restructuring that allow to understand the role loss of local commercial systems (Lluch, Nel.lo 1984). Three general explanatory processes can be isolated: firstly, the maintenance of commercial power centralization around Barcelona despite the incipient role of the other three province capitals; secondly, the articulation of center-periphery dynamics at the scale of county and provincial capitals as a result of an increasing metropolitanization (Frago 2011); finally, the general commercial desertification that since 2008 affects the whole territory, and especially these county capital cities. This process of desertification means that the opening of new commercial shops is restricted only to shopping malls and tourist commercial axes, as an outcome of the growth of e-commerce.

The growing territorial integration around Barcelona has meant the dissolution of the capacity of terri-

\footnotetext{
${ }^{10}$ IDESCAT, 2019.

11 The initial proposal of 1936 was 38 counties; in 1987, after the Franco regime, there were 41 ; and in 2015, Moianès was incorporated as the $42^{\text {nd }}$ county.

${ }^{12}$ For a better understanding of the articulation of urban macrocephaly, see O espaço dividido (Santos 1979) and Paris et le désert français en 1972 (Gravier 1972).
} 
torial articulation by the county capitals. At the same time, the processes of urban agglomeration around the provincial capitals have been driven by the State, both from its political and administrative functions and from infrastructure investments. For instance, in Tarragona, there has been implemented an important specialization on the petrochemical sector. This process, however, has been unable to generate robust and autonomous metropolitan dynamics that at the same time were able to counteract the concentration of main tendencies around Barcelona. The modernization by the State of consumer spaces also has been boosted mainly through a Higher Education Policy that has looked for decentralization of Universities from Barcelona to the provincial capitals. However, the small number of students and the suburban location of the campuses have not helped to generate other dynamics of consumption's concentration.

In the Tarragona area, since the 1960's to the present day, the antagonistic coexistence between the petrochemical industry and tourism, both national and international, has been intensified. It has contributed to this fact the opening of the leisure complex of Port Aventura in 1995, with 5 million visitors (2018), the declaration of the city as UNESCO Heritage (in 2000) and the use of Reus airport by low-cost airlines, doubling the number of passengers over the last 5 years, reaching 1.3 million passengers in 2019. Although the process of territorial rescaling of the area of Tarragona has led to a significant increase in urban complexity, it should be underlined that no metropolitan political or administrative entity has been created ${ }^{13}$.

The urban agglomeration around Girona and its province is specialized in tourism, mainly because it is one of the gateways to Spain for millions of European tourists going to the Mediterranean. Tourism is also an important driver of the economy behind Tarragona and Reus, in contrast of the most strategic economic sector in Lleida around the agro-industries, specialized in fruit and derivatives' exports. A differentiating feature of the Lleida area is also its ability to organize the daily consumption of large territories, beyond the Catalan border. Although tourism is more exceptional than in the other provinces, the Aran and the Bohí valleys, both in the Pyrenees in Lleida, are areas linked to snow sports during winter and hiking on summer.

Territorial rescaling has meant a major restructuring of consumption spaces on a local scale. From the 1990's onwards, a new territorial order consolidates at the local level based on the restructuring and redevelopment of

${ }^{13}$ The Camp de Tarragona Partial Territorial Plan, approved in 2010, was the first plan that considered a functional area. urban spaces as an outcome of the impacts of metropolitan integration and global circuits of capital, commodification and labor. Responsibilities lie with both capitalist dynamics, especially the growing role of the urban land market, and the State, with its territorial and urban planning. The most important changes have been, firstly, the restructuring of the main areas of daily consumption as a result of the integration of regional capitals in the new global and metropolitan areas (Frago 2011) and, secondly, the refunctionalization of many agricultural areas towards international logistic activities because of the proximity to the main international corridors (Frago 2015).

The new territorial order of the regional capital's consumption spaces has been characterized by the articulation of urban totalities that endow these cities with center-periphery dynamics because of their metropolitan integration. The opening of new supermarkets and hypermarkets was synchronous and directly related to the building of new low-density neighborhoods, which emerged from the 1990's. At the same time, these new commercial areas also attracted consumers from other cities and the surroundings that had traditionally gone to the historical city center, the only space that had meant the city whole until then. On the other hand, dialectically, the traditional space of consumption corresponding to the historical center underwent significant changes, in most cases a slowdown.

The different paths followed by the historical city centers metamorphosis of the county capitals exemplify the restructuring of the consumption spaces as an adaptation to the new totalities. As a general process, three different paths of the urbanization can be identified: first, a general devaluation, second the maintenance of centrality or centrification ${ }^{14}$, and third as a mixed path, and even a more selective one, that materializes in devaluation or revaluation street by street. In the first case, the modernization has been characterized by a general housing disinvestment, accompanied at the same time by a dissolution of the centrality produced by massive closure of retail and service shops, especially significant when it has affected the main street, as is the cases of Valls, Tortosa, Balaguer, Cervera, and Berga. In the second case, when centrality is maintained or a process of centrification takes place, the business strategy is aimed at diversifying and expanding the catering offer. In addition, it is aimed, mainly in the early stages

\footnotetext{
${ }^{14}$ Concept that was created to overcome the one of gentrification, so trivialized in recent years as a result of the growing weight of urban land value in all urban processes and consequently the loss of explanatory validity of the rent gap (Carreras 2010).
} 
of the process, the opening of internationally renowned shops interested in catching the demand, but the concentration of consumption around online shopping has slowed down, as in the case of Reus, Vic, Vilafranca del Penedès, Mataró and Granollers. As it has been pointed out, in other cases, the process has been more selective, and as some streets have experienced a strong real estate and functional devaluation, other streets or squares have remained central or have been modernized to adapt to the new consumers' demand, as in the case of Tarragona, Igualada, Lleida or Manresa (Frago 2011).

To these three paths of the historical city centers as spaces of consumption at the Catalan level, it must be added a general phenomenon: the closure of retail activities that acted as an anchor for hundreds of other retail shops in those more dynamic historical city centers. The best example of this effect has been that of fast fashion brands with a high capacity to attract consumers, such as those of the INDITEX, Mango or H\&M groups. The shops closure in the high streets of historical city centers has led to the dissolution of the concentration of consumption in these places and a step towards dispersion, affecting even the largest provincial capitals and county capitals.

The closure of such activities generates the crisis in the main commercial axis of the city centers, where many other shops took advantage of the attraction exerted by these commercial chains. The deconcentration of the historical center of the city is identified in important regional capitals such as Mataró, that in 2018 the two stores of INDITEX group closed, remaining open only those of the Mataró Parc shopping center, inaugurated in 2000 and located on the outskirts of the city and attached to a motorway. Further south of Catalonia, in Reus or Tarragona, the stores of these international brands have also closed over the last 5 years. These shops were concentrated in the shopping mall of the Central Park of Tarragona (inaugurated in 1997) and the Reus Trade Fair (opened in 2015), as well as in the Les Gavarres Commercial Park (opened in 1998), halfway between the two cities.

The process of historical city center deconcentration and the complementary dispersal to the suburban shopping malls and shopping parks have also occurred in dense metropolitan cities. In Badalona, in the metropolitan area of Barcelona, ZARA shop closed in 2013, resting only open the one located in the Màgic Badalona shopping center. While the business strategies of these brands detract dynamism of relatively large cities, in the smaller county capitals the slowdown is even deeper.
3.2 The global integration of inner territories: the role of the logistic activities

While the daily supply system has become more and more fragile, as it has been pointed out, there has been at the same time a global integration of the regional territory through the articulation of large logistic corridors aimed to connect the major metropolises of the world. Although the two main nodes that materially connect with global mobility, the seaport and the airport, are located very close to Barcelona, it is important to highlight the recent metamorphosis of the regional territory. This territory has changed its function, from the local supplying to an international scope. An example is the case of Valls: while its role in local structuring has been diminished, several logistic centers of international wellknown brands, as IKEA, supply from there several countries in the south of Europe (Frago 2015).

The connection of metropolitan areas to great communications corridors has meant that some territories that were far away from the city direct influence, have now acquired a new relative position in the context of planetary urbanization (Brenner 2019). In this way, in Sallent, 80 kilometers away from the center of Barcelona, it was established the logistic center of Stradivarius, a branch of the group INDITEX, supplying whole Spain, southern France and northern Italy. The proximity to one expressway, that allows the French-Spanish connection avoiding Barcelona, is one of the main location factors, reaffirming the loss of role of the city's direct influence in the location of these activities.

Territorial rescaling has been the product of spatial strategies developed by the State for several decades. Nevertheless, it has been strengthened with its neoliberal management, and since then it has invested especially in infrastructure aimed to connect the big world metropolises. In this frame, the Spanish state invests in the construction of infrastructures of international scope, as motorways and expressways. Even transport nodes such as the airport (new terminal in 2009), the seaport (BEST terminal opened in 2012) and railway terminals (arrival of the high-speed train to the French border in 2013) ${ }^{15}$. Moreover, since 1992 the State invested directly in the construction of international logistic centers through CIMALSA $^{16}$. Since the 19th century, the Spanish state

\footnotetext{
15 There is a progressive neoliberalization of the exploitation of stateowned infrastructure. Especially for the Spanish case is the private operation of Puertos del Estado and the railway lines of the public company ADIF (Frago 2016).

${ }^{16}$ CIMALSA is a public company of Catalan Government, responsible for the promotion, development and management of distribution and logistics centres.
} 
has invested in conditioning the space, especially aiming to a spatial integration at the level of the Spanish scale. Moreover, for shorter periods, when the regional government has been endowed with some political power, has integrated the space from a Catalan logic. Especially significant was the effort made by the Mancomunitat de Catalunya (1914-1923) ${ }^{17}$ which, despite its short existence, modernized communications on a Catalan scale, especially the telephone network.

The relative position of the territory with respect to the large corridors of international tourism has also meant a territorial rescaling from the opening of shopping and consumer centers aimed to catch the tourist incomes. As an example, it could be shown the opening of the Roca Village outlet shopping center in 1998. It currently has more than 120 luxury brands and concentrates almost $20 \%$ of tourist purchases in Spain using the VAT return system. This outlet attracts tourists from Barcelona and the Costa Brava, as well as those who are passing by the eastern Spain coasts and other European countries. Following the same logic in 2016 the Style Outlets was opened in Viladecans, five kilometers away from Barcelona airport ${ }^{18}$.

\subsection{The extension of metropolitan areas}

The logics of the restructuring and expansion processes of the new centralities, and of the metropolitan specializations are more explained for the rescaling of the territory of each municipality than by a dynamic of endogenous capital concentration, which is able to counteract the macrocephaly of Barcelona. This process has not been the same in closer areas to the metropolitan core than in the more remote territories. In the closest municipalities to Barcelona, the new centralities are directly related to a concentrated urbanization. This kind of urbanization is related to centrality functions, which should be located within the capital. Examples are the City of Justice or the Fira Barcelona Gran Via (International Exhibition Center), both located in the municipality of L'Hospitalet de Llobregat. In the most remote municipalities, but close to the main regional infrastructures, such as airports, motorways, expressways and business parks, there has been a territorial rescaling

\footnotetext{
17 The Mancomunitat de Catalunya was a deliberative assembly made up of the councilors of the four provinces of Catalonia created in 1914 and disbanded in 1923. It was responsible for the creation of many public institutions in health, culture and technical education and science.

${ }^{18}$ In general tourists concentrate their commercial expenses in the last 3 days of its stay, so the location of this kind of shopping centers and outlets near the airports is very strategic.
}

based on extensive urbanization. Shopping malls that follow these location patterns are a good example.

The Llobregat Delta plain is a territory where many shopping malls have been built on old agricultural uses along the axis of the C-31 expressway and C-32 motorway, that connect the Garraf county with Barcelona. The pattern of dispersion of those shopping malls has come motivated by high municipal fragmentation. Nine shopping centers are located in this area of approximately eighty square kilometers. Each one is in a different municipality ${ }^{19}$ (Fig. 2).

\section{Barcelona, a commercial centre with no periphery?}

Into this changing Catalan urban system, Barcelona at large undoubtedly plays the central role in many different aspects: politically administrative, culturally, economically, even in the retail organization. At the same time, into the contemporary retail restructuration Barcelona has a clear central area. However, in a long metropolitanization process, based on the population and economic hypermobility at different scales, centrality is not a function of the quantity or quality of the goods and services offered (Beavon 1977). The reduction of times of transport and connection creates new spaces with variable geometries in a complex overlay of global and local trends. Urban planning has also promoted new centralities at municipal, metropolitan and regional scales. Barcelona designed in 1987 an ambitious plan with ten new central areas for its economic and urban redistribution and promotion (Busquets 1987), never completed.

In addition to that, it is necessary to integrate the complexity on the urban organization. The traditional dualistic theory of the dialectics between centre and periphery needs a reconsideration (Carreras 2017). The original geopolitical theory appeared in urban analysis on the sociology Chicago school at the beginning of $20^{\text {th }}$ Century, and was developed later for the Tertiary activities in different directions by many Geographers like Walter Christaller, Raymond Murphy, Brian Berry or Neil Smith. Theory could remain explicative in the geopolitical domain, in spite of the difficulty to locate with accuracy the contemporary centre. However, the urban space organization is more complex than the Chauncy

19 Carrefour shopping park (former PRYCA, opened in 1974) in El Prat de Llobregat; Barnasud (1995) in Gavà; Sant Boi Shopping Center (1990s) in Sant Boi del Llobregat; Gran Via 2 (2002) in L'Hospitalet de Llobregat; the T1 Shopping Center at Barcelona Airport (2009) in el Prat de Llobregat; Vilamarina (2009) in Viladecans; Splau! (2010) in Cornellà de Llobregat; Ànec Blau (2010) in Castelldefels; Style Outlets (2016) in Viladecans and Finestrelles (2018) in Esplugues de Llobregat. 


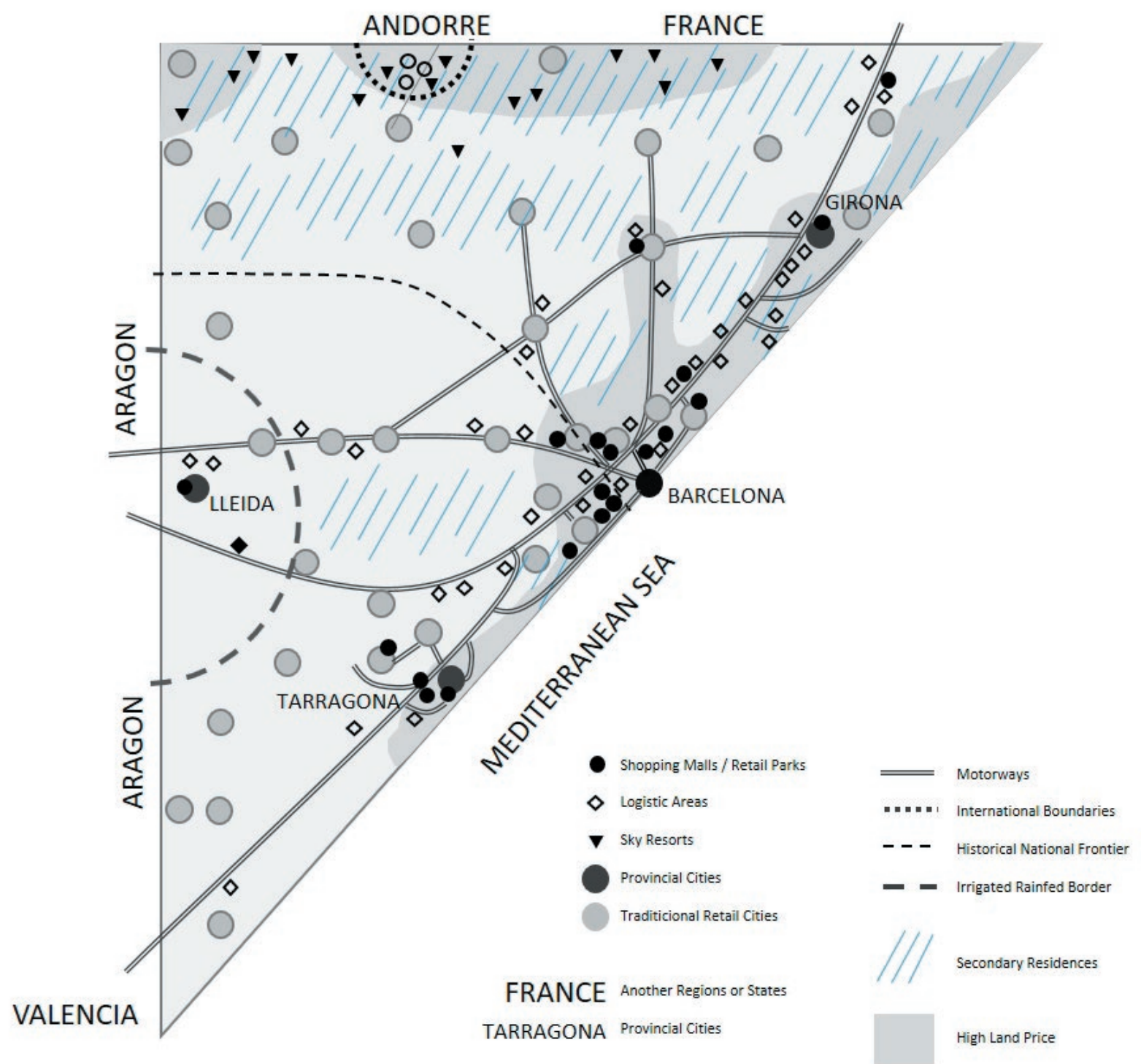

Figure 2. A schematic map of the main consumption spaces in Catalonia. Source: Bernardos et al. 2020.

Harris and Edward Ullman 1945 multiple nuclei model, because on a functional analysis there exists a changing overlapping of the influence areas of each nucleus, independent of their quantitative hierarchy.

The figure 3 tries to be a synthesis map of the commercial structure of the city, with the location of the main present retail points of Barcelona at the end of the second decade of the 21st Century. Nevertheless, the myriad of non-represented shops of the defined first level, organized around the municipal markets and other commercial centres, were dramatically decreasing. Many shops were vacant and many other changed their use, mainly to residences. This real retail apocalypse affected also the department stores ${ }^{20}$ and the shopping centres. The consequences of the pandemic lockdown of 2020 seems to predict an increase of this apocalypse.

However, the Shopping line, the real commercial centre first defined by the authors in $1990^{21}$, is always

${ }^{20}$ El Corte Inglés sold in 2019 one of its central building, temporary maintaining his commercial activity.

${ }^{21}$ In this pioneer study, authors described a linear center of $5 \mathrm{~km}$ length, but the Shopping line was reducer to the half. They also proposed alternatives to adapt some parts of this center as a living mall, in the way of BID's, but never implemented. 


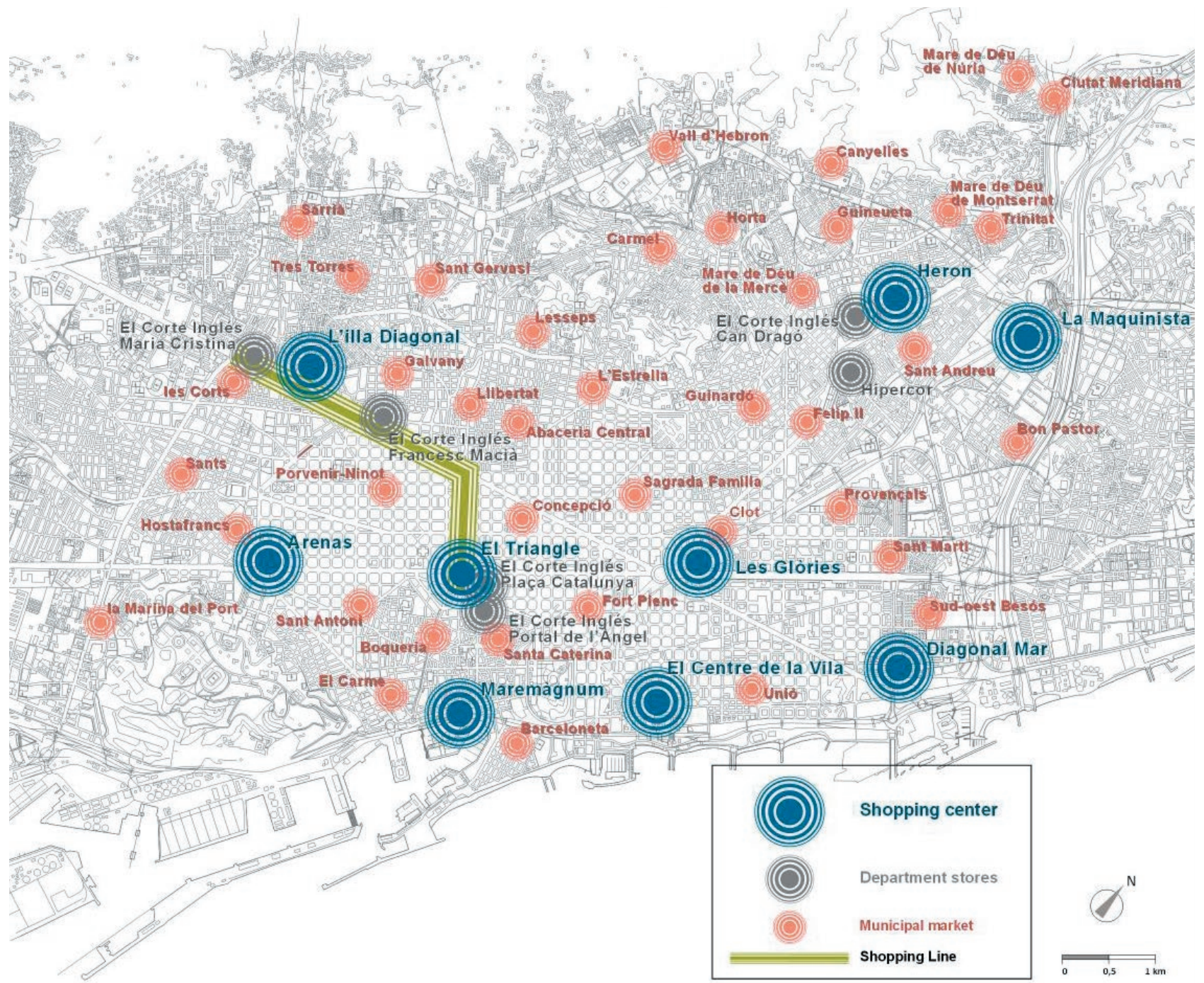

Figure 3. The commercial structure of Barcelona in 2017, according to the authors. Source: Carreras et al. 2019, 109.

alive, especially because the Barcelona's tourism board ${ }^{22}$ created its trademark on the wake of the summer Olympics of 1992, through the voluntary association of many of its different firms. The origin itself of this official initiative clearly manifests the leadership of the tourist sector, not of the retail. As usual, local big retailers maintained their traditional competitiveness more than cooperation (Carreras 2006). The old expensive fashion and jewellery shops were progressively replaced by flagship and franchised international companies; cinemas and high-class restaurants by the Mediterranean fast food of

${ }^{22}$ Vid: https://www.barcelonaturisme.com tapas $^{23}$; the banks disappeared ${ }^{24}$; bourgeois art nouveau residences were converted to museums ${ }^{25}$.

The centre of the city is not anymore a commercial one; this new centre does not organize any influence area all around, and for this reason, it is possible to speak about a centre with no real periphery. In fact, it is the target area of national and international visitors,

\footnotetext{
${ }^{23}$ Appetizer or snack typical of the Spanish cuisine.

${ }^{24}$ The strong concentration of financial firms during the 2007 crisis, and the later closing of many branches and offices because the computerization of processes reinforced the effects of the apocalypse of commercial premises. In 2000 there were in the city 2.121 bank offices and in 2018 only 817, according to the Statistical Yearbook of Barcelona.

${ }^{25}$ One of the authors is doing a long and deep research on the historical evolution of the main avenue of the Shopping line.
} 
is a tourism centre of attraction. Relevance of tourism in Barcelona clearly appears in all kind of statistics. The majority of visitors use the international airport, giving the most spectacular proof of this relevance. Almost 20 million passengers in 2000 and more than 50 in 2018 were registered; in the same years, passengers of cruisers were 573.000 and more than 3 million. In addition to that is necessary to consider the proximity of many European countries that allows communication also by train, car and ferry.

Many visitors did the so-called commercial tourism, especially afforded people coming from farthest countries in other continents (mainly Americans, Japanese and Chinese) enlarging the market area of the local Shopping line to a global scale ${ }^{26}$. In spite of the fact that the foreign visitors spend only few days in the city, the constant and massive ${ }^{27}$ presence of different tourist groups almost all around the year ${ }^{28}$ represents an important commercial demand ${ }^{29}$.

On the way of the urban restructuration promoted by the organization of the 1992 summer Olympic Games, one commercial and tourist policy was implemented. Into the campaign Barcelona posa't guapa ${ }^{30}$ looking the central façades renovation, municipality organized a sort of contest rewarding the best-preserved nicest shops with a century of tradition. The aesthetics was clearly prior to the dynamics of commercial activities, on the way of the landscape architecture. Municipality has a catalogue of iconic shops protecting retail and promoting their visit. It was a local policy subordinating economy to the monumentalization. Finally, the retail apocalypse has visibly closed many of these iconic shops (Carreras, Frago 2016)

The iconic streets and avenues of central Barcelona transformed the old commercial centre in a symbolic place. The Shopping line today is a tourist centre, with mainly international shops. The problem is that other well-located iconic parts of the city, like the Gothic quarter or the Sagrada Familia, compete with the Shopping line with their images largely diffused everywhere on social media. These different attraction areas are not real centres with the capacity to organize and articulate larger territories of influence, but concentration zones.

\footnotetext{
${ }^{26}$ In 2018, with more than 13 million tourists, the retail expenses per capita and day were of $17,72 €$.

${ }^{27}$ In 2000, there were more than 3 million tourist in the city, and in 2018 more than 13 .

${ }^{28}$ January and December are the month with less tourist in the city, but with a reduction only of the $30 \%$.

${ }^{29}$ The mobility collapse of 2020 is the best argument of the former touristification with the desertification of the city centre.

${ }^{30}$ Barcelona make yourself beautiful.
}

Alternatively, simply it could be suggested that they are centres with no peripheries.

As already analysed, after the process of deindustrialization, the Barcelona municipality chose to encourage the tertiarization at large, planning an important decentralization of the business offices. However, into the wide range of activities included in the service sector the consumer services were the most privileged. The international success of the 92' Olympics balanced the hegemony to all activities connected to national and international tourism, as all kind of local statistics show. In conclusion an extremely biased tertiarization, with clear strengths and weaknesses: strengths were in the social and economic, even cultural enrichment and weaknesses in the fragility of the images ${ }^{31}$, in the serious conflict between residents and visitors ${ }^{32}$ and the high dependence of the communication infrastructures ${ }^{33}$.

\section{The future of Barcelona consumer's society: some final remarks}

Future is always inscrutable, but the knowledge of the past and present allows suggesting some scenarios. In this regard, the evolution of the spatial structure of the retail and consumption in Catalonia and Barcelona is uncertain, but under the light of some trends some of these scenarios could be suggested or imagined, which is left to do. The dialectics between some selected dualities could be probably the best way to think the possible evolution of the Barcelona consumer society at its different scales. Even to choose a way to undertake some political interventions.

There are different important conflictive trends that make difficult any forecast. The opposition between small and big shops is irrelevant at a territorial level, because small shops and retail corners form the big shopping centres or the magazine stores. However, the real conflict is between small and big firms where the second will always win the competition, especially with the increasing process of capital accumulation. The conflict between urban and suburban retail, by the so-called proximity, depends on the evolution of private cars and

\footnotetext{
31 Pictures of riots and social and political protests counteract nice images. Especially critic was the diffusion of the terrorist attack on August the $17^{\text {th }}, 2017$ in the symbolic avenue of Ramblas.

32 Many demonstrations against tourists were organized in different neighborhoods; graffiti with slogans like tourist you are a terrorist or tourist not welcome. The popular idea was that tourism enlarges the urban land market generating difficulties for housing locals.

33 Stop of flights during the pandemics of 2020 paralyzed all visits, with
} an uncertain future. 
the future of agglomerations itself. Automotive industry is very powerful, with a capacity of adaptation to new energy sources, and it does not seem very realistic a noticeable reduction of car production or consumption; more after the pandemic that makes suspicious all kind of public transportation. In the Barcelona area, the bicycle could have already reached its maximum. The conflict local-global at the short term will reduce the different alternatives to globalization a very symbolic role. It is necessary to think that nationalist challenges to Globalization will remain only overacting of few mediocre leaders. Finally, the tension between commercial freedom and its legal regulation will with no doubt balance to the first.

Fragility and uncertainty could be the best conclusion. Fragility of everything after pandemics resolutions expressed for many people in the media and in the social networks. It looks very similar to the every New Year personal resolutions. As expressed by the French controversial novelist Michel Houellebecq on the Italian journal Il Corriere della Sera in May 2020: after all it will be the same, but a little bit worst.

Fragility especially of the economies, like the Barcelona and Mediterranean countries, excessively based on global tourism. The big tourist success of the last decades is in a strong divide. Continuity of global tourism needs possibilities; it is infrastructures, especially aerial connections, regulations allowing flights and passenger's mobility and tourists with money and feeling like spending it. All of that depends on a sum of multiple decisions, many of them outside the reach of the local, but the monopolistic tour operators, aerial companies or hotel chains are as affected as the universes of small and medium size local firms. In Barcelona, authorities and citizens must seriously consider their experience in the recent anti touristification movements in the wake of the total paralysation of all of that.

\section{References}

Arribas, L. (2002). Importing The French Retail Planning Model to Spain. In De Jong, M., Lalenis, K., Mamadouh, V. (Eds.). The Theory and Practice of Institutional Transplantation. Dordrecht, Kluwer Academic Publishers, 87-101.

Beavon, K. (1977). The Central Place Theory: a Reinterpretation. London, Longman.

Bernardos, G. et al. (Eds.). (2020). Viladecans. Una historia de éxito. Lleida, Editorial Milenio.
Bohigas, O. (1986). Reconstrucción de Barcelona. Madrid, Dirección General de Arquitectura y Edificación.

Boix, R., Galletto, V., Trullén, J. (2011). BCN metròpoli creativa. Informe $i$ mapes urbans de coneixement $i$ innovació de Barcelona. Barcelona, Ajuntament de Barcelona.

Brenner, N. (2014). Implosions/explosions: towards a study of planetary urbanization. Berlin, Jovis.

Brenner, N. (2019). New urban spaces: urban theory and the scale question. New York, Oxford University Press.

Busquets, J. (Ed.). (1987). New downtowns in Barcelona. Barcelona, Ajuntament de Barcelona.

Carreras, C. (1989). Per una nova geografia comercial urbana. Revista Catalana de Geografia, 4 (10), 2-16.

Carreras, C. (2003b). La Barcelona literària: una introducció geogräfica. Barcelona, Proa.

Carreras, C. (2006). Tradition and Modernity. Competition among retail location in contemporary Barcelona. Belgeo, 31, 41-52.

Carreras, C. (2010). La centrificación, una propuesta de clarificación conceptual. In Martinez-Rigol, S. (Eds.). La cuestión del centro. El centro en cuestión. Lleida, Pagès Editors, 37-42.

Carreras, C. (2017). El centro de la ciudad postgentrificada en la sociedad de los consumidores. In Gasca, J. (Eds.). Espacios del consumo y del comercio en la ciudad contemporánea. México, UNAM, 17-34.

Carreras, C. (Ed.). (2003a). Atles Comercial de Barcelona. Barcelona, Ajuntament de Barcelona.

Carreras, C. et al. (2019). Consumo y comercio en Barcelona. Actualidad y tendencias. In Viganoni L. (Eds.). Commercio e consumo nella città che cambiano. Napoli, città medie, spazi sterni. Milano, FrancoAngeli, 101-150.

Carreras, C., D’Alessandro, L. (2017). Un repertorio bibliografico su commercio, consumo e città. In Viganoni, L. (Eds.). Commercio, consumo e città. Quaderno di lavoro. Milano, FrancoAngeli, 27-69.

Carreras, C., Domingo, J., Sauer, C. (1990). Les àrees de concentració commercial de Barcelona. Barcelona Ciutat de compres. Barcelona, Cambra Oficial de Comerç, Indústria i Navegació.

Carreras, C., Frago, Ll. (2016). Patrimonio commercial y turismo. Los establecimientos comerciales de Barcelona. Cenário, 4 (6), 9-26. https://doi.org/10.26512/revistacenario.v4i6.18297 
Florida, R. (2002). The Rise of the Creative Class: and How it's Transforming Work, Leisure, Community and Everyday Life. New York, Basic Books.

Frago, Ll. (2011). La metamorfosi del centre a les capitals comarcals: entre tradició i postmodernitat. Doctoral thesis report. Barcelona, Universitat de Barcelona.

Frago, Ll. (2015). Logística y reestructuración metropolitana en el área de Barcelona. Scripta Nova. Revista Electrónica de Geografía y Ciencias Sociales, 19, 1-15. http:// www.ub.es/geocrit/sn/sn-523.pdf

Frago, Ll. (2016). Pôles logistiques métropolitains et stratégies territoriales dans l'aire urbaine de Barcelone. Sud-Ouest Européen. Revue Géographique, 41-42, 155171.

Garcia-Canclini, N. (1995). Consumidores y ciudadanos. Conflictos multiculturales de la globalización. Mexico, Editorial Grijalbo.

Gravier, J.-F. (1972). Paris et le désert français en 1972. Paris, Flammarion.

Harvey, D. (1989). From Managerialism to Entrepreneurialism: the Transformation in Urban Governance in Late Capitalism. Geografiska Annaler, Series B, Human Geography, 71 (1), 3-17.

Hutton, T. (2010). The New Economy of the Inner City: Restructuring, Regeneration and Dislocation in the Twenty-First-Century Metropolis. London and New York, Routledge.

Lefebvre, H. (1970). La revolución urbana. Madrid, Alianza Editorial.

Lluch, E., Nel-lo, O. (1983). La gènesi de la Divisió Territorial de Catalunya. Barcelona, Diputació de Barcelona, 2 vols.

Lluch, E., Nel.lo, O. (1984). El debat de la Divisió Territorial de Catalunya. Edició d'estudis, propostes i documents. Barcelona, Diputació de Barcelona.

Montesinos, E. (2019). De la ciudad industrial a la ciudad creativa: las transformaciones urbanas de Barcelona en el siglo XX. Doctoral thesis report, Barcelona, Universitat de Barcelona.

Nogué, J. (1991). Els Nacionalismes i el territori. Barcelona, El Llamp.

Pareja-Eastaway, M. et al. (2008). The city of marvels? Multiple endeavours towards competitiveness in Barcelona. Pathways to creative and knowledge-based regions. Amsterdam, Universiteit van Amsterdam.
Santos, M. (1979). O espaço dividido: os dois circuitos da economia urbana dos países subdesenvolvidos. Rio de Janeiro, F. Alves.

Santos, M. (1996). A natureza do espaço: técnica e tempo, razão e emoção. São Paulo, Hucitec.

Scott, A.J. (2008). Social Economy of the Metropolis. Cognitive-Cultural Capitalism and the Global Resurgence of Cities. New York, Oxford University Press.

Smith, N. (1984). Uneven development: nature, capital, and the production of space. Oxford, Basil Blackwell.

Vila, P, (1937). La divisió territorial de Catalunya. Barcelona, Conselleria d'Economia, Generalitat de Catalunya.

Vilar, P. (1962). La Catalogne dans l'Espagne moderne. Recherches sur les fondéments économiques des structures nationales. Paris, SEVPEN (EPHE), 3 vols.

Vives, J. V. (1962). Notícia de Catalunya. Barcelona, Destino. 